\title{
VDAC2 Gene
}

National Cancer Institute

\section{Source}

National Cancer Institute. VDAC2 Gene. NCI Thesaurus. Code C37293.

This gene is involved in small molecule transport and apoptotic regulation. 